\title{
A ação coletiva da classe patronal de Porto Alegre nas grandes greves da Primeira República (1917-1919)
}

\author{
César Augusto Bubolz Queirós*
}

Resumo: Este artigo tem o objetivo de analisar as estratégias utilizadas pela classe patronal de Porto Alegre nos embates com o movimento operário organizado e suas associações nas grandes greves da Primeira República. Pretendo demonstrar que esse período proporcionou um processo de tomada de ações coletivas e de um verdadeiro fazer-se da classe patronal, que passou a atuar de modo organizado nas negociações com os trabalhadores grevistas.

Palavras-chave: Patronato, Greves, Movimento Operário

Abstract: This paper aims to analyze the strategies employed by the Porto Alegre's employer class during the Brazilian's First Republic period strikes. I intend to show that this period provided a process of taking collective action and make a real up the employer class, which began operating in an organized manner in the negotiations with the striking workers.

Keywords: Employers, Strikes, Labor Moviment

Ao longo da Primeira República, os confrontos entre o patronato e a classe operária organizada no estado do Rio Grande do Sul foram uma constante. As greves se sucediam com velocidade e dinâmica espantosas - sobretudo, no período entre 1917 e 1919 - e, por mais que houvesse repressão da parte da força pública, parecia que esses movimentos nunca se extinguiriam. ${ }^{1} O$ patronato porto-alegrense (e aqui me refiro, em especial, aos proprietários de estabelecimentos industriais e manufatureiros), por sua vez, passou a adotar estratégias coletivas diante da erupção dessas mobilizações paredistas que teimavam em estourar na capital. Neste artigo, procurarei analisar as estratégias coletivas utilizadas pela classe patronal porto-alegrense para enfrentar o movimento operário organizado e suas associações durante as grandes greves da Primeira República. Darei ênfase à greve de 1919, em virtude de que, durante esse movimento paredista, ao contrário das greves de 1917 e 1918, a maioria das reivindicações dos sindicatos classistas foi dirigida ao patronato, transformando-o no principal interlocutor dos grevistas.

* Doutor pela UFRGS

1 Sobre as greves nesse período, ver: QUEIRÓS, César Augusto Bubolz. Estratégias e Identidades: as relações entre governo estadual, patronato e trabalhadores nas grandes greves da Primeira República em Porto Alegre (1917-1919). Tese (Doutorado em História). Porto Alegre: UFRGS, 2012. 
Em 1917 e 1918, talvez por causa da influência da carestia provocada pelo cenário internacional conturbado, as reivindicações foram dirigidas prioritariamente ao governo do estado. Tratava-se de uma disputa entre interesses evidentemente incompatíveis, durante a qual os patrões foram, gradativamente, organizando-se como classe, a fim de enfrentarem o repertório de ações coletivas do operariado, repertório este informado por uma longa tradição militante.

Antes, contudo, vou procurar entender quem eram os patrões em Porto Alegre naquela conjuntura e em que ramos atuavam, considerando que "os empregadores são um ator central nos conflitos do trabalho", sendo, juntamente com o estado, "o adversário e o interlocutor privilegiado dos grevistas".'

\subsection{O patronato em Porto Alegre: breve caracterização}

Nesta seção, farei uma breve caracterização da classe patronal de Porto Alegre no contexto das grandes greves da Primeira República, com o objetivo de conhecer quem eram esses industriais ou empresários, destacando seus ramos de atuação e a mão de obra que empregavam. Não pretendo, aqui, ressalva-se, fazer uma história da industrialização em Porto Alegre, uma vez que outros trabalhos já se debruçaram justamente sobre esse ponto. ${ }^{3}$

Inicialmente, cabe ressaltar que a industrialização em Porto Alegre, no início do século XX, possuía um caráter muito incipiente, com indústrias de baixa tecnologia, em geral manufaturas, empregando pouca mão de obra; eram os proprietários desses estabelecimentos, enfim, que faziam os embates com o proletariado durante as greves aqui estudadas, em um "panorama industrial [...] quantitativamente dominado pelos pequenos estabelecimentos". ${ }^{4}$ Apesar desse predomínio das unidades produtivas de pequeno porte, com baixa ou nenhuma utilização de maquinário, e escasso emprego de mão de obra, o desenvolvimento industrial no estado se deu "pela progressiva tecnificação [sic] de algumas empresas líderes, que se impuseram no mercado e se tornaram responsáveis pelo dinamismo do setor". 5

O patronato da capital, portanto, era composto por um considerável número de proprietários de pequenos estabelecimentos industriais e comerciais, e de um reduzido, mas significativo, número de empresas que apresentavam volumosa soma de capital investido; ampla utilização de maquinários, importados, sobretudo, da Europa; e considerável quantidade de mão de obra empregada. Em suma, de um lado, um grupo reduzido de empresas líderes, e, de outro, "um grande número de pequenas empresas, com reduzido capital, caracterizadas pela presença do trabalho artesanal predominante frente a um quase inexistente número de máquinas". ${ }^{6}$ Nesse sentido, Reichel salienta o fato de que "ao se comparar os números referentes às medidas do capital e mão-de-obra empregados por unidade, verifica-se que a indústria do Rio Grande do Sul se apresentava formada por pequenas empresas com baixo volume de capital investido". ${ }^{7} \mathrm{Na}$ mesma linha, a

2 SIROT, Stéphane. La Grève em France: une histoire social. (XIX-XX siècle). Paris: Odile Jacob, 2002, p. 201.

3 Ver, por exemplo: PESAVENTO, Sandra Jatahy. A Burguesia Gaúcha: dominação e disciplina do trabalho. Porto Alegre: Mercado Aberto, 1988; SINGER, Paul. Desenvolvimento Econômico e Evolução Urbana (análise da evolução econômica de São Paulo, Blumenau, Porto Alegre, Belo Horizonte e Recife). 2.ed. São Paulo: Nacional, 1977.

4 PESAVENTO, Op. cit., 1988, p. 20.

5 Idem, p. 21.

6 Ibidem, p. 19.

7 REICHEL, Heloisa Jochims. A Industrialização do Rio Grande do Sul na República Velha. In: DACANAL, José H.; GONZAGA, Sérgius (orgs.). RS: Economia e Política. Porto Alegre: Mercado Aberto, 1979, p. 257. 
respeito da estrutura produtiva do estado naquele período, Aravanis destaca "a coexistência de dois 'tipos' básicos de espaços de produção, bem como, consequentemente, de dois 'tipos' de operários fabris, os artesãos 'das oficinas' e os operários “das fábricas"”. 8

A respeito da Fábrica de Pregos de João Gerdau e Filhos, Marcovitch confirma o caráter semiartesanal e o baixo grau de especialização da produção. Nessa fábrica, a "operação industrial em si era bastante simples. A matéria-prima limitava-se ao arame que chegava da Alemanha em rolos de oitenta quilos. Depois de limpos para a retirada da ferrugem acumulada durante o transporte, eram encaminhados para as máquinas de fabricação de pregos, seguindo-se o controle de qualidade e o empacotamento". 9

O caráter artesanal ou semiartesanal da maioria dos estabelecimentos da capital contrastava com a mecanização existente em algumas empresas que contavam com sofisticado maquinário importado da Europa. A Fábrica Berta, por exemplo, de propriedade de Alberto Bins ${ }^{10}$, possuía instalações que, sob a ótica de um visitante, estavam "repletas de máquinas dos tipos mais modernos e custosos"." Uma descrição da Companhia Fiação e Tecidos Porto-Alegrense ${ }^{12}$ informava que a “fábrica tem 85 teares e 112 outras máquinas, aperfeiçoadíssimas. Seu motor é da força de 250 cavalos. Duas grandes caldeiras fornecem vapor para o motor e para todos os serviços da fábrica. Possui também a companhia, para consertos necessários nos seus maquinismos, oficinas de ajustadores e carpinteiros". ${ }^{13}$ Constituía-se para a época retratada em um verdadeiro "jardim industrial”, com "vastas colmeias, onde os obreiros atuam febrilmente". ${ }^{14}$

Essa progressiva mecanização da produção levava as empresas a produzirem cada vez "mais e em melhor tempo, o que permitia à indústria equiparar-se, em termos de mercado, a concorrentes melhor aparelhados". ${ }^{15}$ Tal desenvolvimento tecnológico era vigorosamente amparado em bases tayloristas, as quais pressupunham a valorização da otimização do tempo fabril, da aceleração da produção e da redução do número de operações. ${ }^{16}$ Nesse sentido, por exemplo, a fábrica de Ernesto Neugebauer era dividida em dez seções: "é a fábrica servida por 2 motores a vapor, que acionam 30 máquinas e 10 caldeiras próprias para a fabricação de confeitos. Além disso, há seções de cartonagem e funilaria, sendo esta última servida

8 ARAVANIS, Evangelia. A industrialização no Rio Grande do Sul nas primeiras décadas da República. Revista Mundos do Trabalho, Porto Alegre: UFSC, v. 2, n.3, 2010, p. 152.

9 MARCOVITCH, Jacques. Pioneiros e empreendedores: a saga do desenvolvimento no Brasil. São Paulo: EdUSP, v.2, 2005, p. 274.

10 Alberto Bins foi um dos industriais mais importantes de Porto Alegre. Era proprietário nos ramos da fundição (União de Ferros, Cofres Berta) e da estalagem (Estaleiro Bins). Tornou-se Intendente Municipal após a morte de Otávio Rocha, em 1928. FAUSEL, Erich. Alberto Bins: o merlense brasileiro. São Leopoldo: Rotermund \& Cia. Ltda., s.d.; BAKOS, Margareth. Porto Alegre e seus eternos intendentes. Porto Alegre: EdiPUCRS, 1996; PESAVENTO, Sandra. O Imigrante na Política Rio-Grandense. In: DACANAL, José; GONZAGA, Sérgius (org.). RS: Imigração e Colonização. Porto Alegre: Mercado Aberto, 1992.

11 LLOYD'S, Reginald (edit.). Impressões do Brazil no Século Vinte: sua história, seo povo, commercio, industrias e recursos. Rio de Janeiro: Lloyd's Greater Britain Publishing Company Ltda., 1913, p. 814.

12 Inaugurada em 6 de agosto de 1891, com o capital de Rs. 1.600:000\$000, foram seus incorporadores os srs. Manoel Py, Antonio Chaves Barcellos, Nogueira de Carvalho \& Cia., Antonio José Gonçalves Mostardeiro e o Banco da Província do Rio Grande do Sul. A empresa era administrada por três diretores, eleitos de dois em dois anos.

13 LLOYD'S, Op. cit., 1913, p. 814.

14 Revista Máscara, Porto Alegre, 1922. apud PESAVENTO, Op. cit., 1988, p. 39.

15 PESAVENTO, Op. cit., 1988, p. 21.

16 Pesavento, analisando alguns textos publicados na imprensa gaúcha, mostra a nítida influência dos preceitos tayloristas sobre o empresariado local. PESAVENTO, Op. cit., 1988, p. 23. Sobre Taylor e sua doutrina, ver: RAGO, Luzia Margareth; MOREIRA, Edmundo E. P. O que é Taylorismo? São Paulo: Brasiliense, 1984. 
por um motor elétrico, que aciona 10 máquinas". ${ }^{17}$ A descrição da fábrica prosseguia mencionando que "no próprio estabelecimento [...] trabalham atualmente 150 operários, em sua grande maioria mulheres", afirmando, ainda, que a fábrica "foi premiada com grandes prêmios, medalhas de ouro e prata em exposições do Estado do Rio Grande do Sul, dos Estados Unidos, de Milão e ultimamente na Exposição do Rio de Janeiro, com grande prêmio e diversas medalhas de ouro". ${ }^{18}$

Outra fábrica que se sobressaía por seu maquinário era a F. C. Kessler \& Cia. ${ }^{19}$, na qual eram manufaturadas todas as qualidades de chapéus. Essa empresa, que tinha de 150 a 160 trabalhadores, entre homens e mulheres, possuía de "40 a 50 máquinas de diferentes fabricantes ingleses, incluindo 8 máquinas de coser, movidas a vapor, uma de gravura em ouro para encadernações e uma para a fabricação de caixas de papelão. Todo o maquinismo é acionado por força elétrica, gerada por um motor a vapor de $55 \mathrm{hp}$, fabricada pela casa Steinmüller da Alemanha". ${ }^{20}$

Devo considerar, porém, que esta “[...] burguesia industrial corresponderia a uma fração não-hegemônica da classe dominante" ${ }^{21}$ em um contexto marcado por um capitalismo tardio e dependente. Ao contrário dos demais estados da Federação, nos quais as iniciativas industrializantes surgiram a partir de uma estreita relação com o capital agrário, a industrialização da capital gaúcha teve como ponto de partida o desenvolvimento das atividades econômicas exercidas pelos imigrantes italianos e alemães que colonizaram a depressão central do estado. A acumulação de capital proveniente do surgimento de um excedente originário, no início, de uma agricultura de subsistência que passaria a suprir, depois, as demandas dos grandes centros cafeeiros proporcionou o surgimento de um mercado interno significativo, capaz de alavancar o desenvolvimento manufatureiro e industrial. Esse excedente comercializável produzido às margens dos rios Jacuí, Pardo, Taquari, Sinos e Caí vinha até Porto Alegre, que se transformara em um escoadouro da produção daquelas regiões..$^{22}$ Tal posição foi reforçada por meio da fundação de ferrovias que acabavam por reproduzir rotas comerciais já estabelecidas anteriormente. ${ }^{23}$

Todavia, as primeiras cidades do estado a se industrializarem foram Rio Grande e Pelotas. Essa anterioridade se explica por uma maior participação do capital comercial no Sul do Rio Grande do Sul, antes de 1890, e pela "presença marcante do porto de Rio Grande na navegação de cabotagem, sendo um dos polos estratégicos do comércio colonial, em especial com a região Rio-São Paulo". ${ }^{24}$ Mas, a despeito dessa precedência, no início do século XX, a capital já apresentava maior quantidade de estabelecimentos industriais em funcionamento. A própria estrutura industrial verificada em Porto Alegre e naquelas duas cidades diferia bastante:

Em Rio Grande, principalmente, ela se caracterizava por apresentar grandes estabelecimentos, com índices de capital e mão-de-obra em-

17 Idem, p. 817.

18 Ibidem.

19 A fábrica de Chapéus de Félix Christiano Kessler foi fundada em 1907 com o nome Mayer e Kessler. Em 1908, com a saída de Mayer, a fábrica passou a chamar-se F. C. Kessler \& Cia. e a ter como sócio Frederico Dexheimer. A fábrica se localizava na Rua dos Voluntários da Pátria e, em 1913, era considerada “uma das mais importantes fábricas do Estado do Rio Grande do Sul”, produzindo "todas as qualidades de chapéus". LLOYD'S, Op. cit., 1913, p. 817.

20 Idem, p. 819.

21 PESAVENTO, Op. cit., 1988, p. 13.

22 SINGER, Op. cit., 1977, p. 172.

23 Sobre o desenvolvimento das ferrovias no Estado, ver: DIAS, José Roberto Souza. Caminhos de Ferro do Rio Grande do Sul. São Paulo: Editora Rios, 1986.

24 HARDMAN, Francisco; LEONARDI, Vitor. História da Indústria e do Trabalho no Brasil. São Paulo: Global, 1982, p. 66. 
pregada acima das médias e pouca diversificação dos ramos industriais (tecelagem, charutos, conservas alimentícias). Já em Porto Alegre, havia um núcleo muito maior de fábricas que, apesar de se constituírem, em média, de pequenos capitais, apresentavam uma maior diversificação industrial. ${ }^{25}$

Em um censo industrial realizado no ano de 1920, observa-se que Porto Alegre empregava $24,3 \%$ de todos os operários de indústrias do estado, contando com 221 estabelecimentos contabilizados. ${ }^{26}$ Entre eles, posso mencionar os segmentos mais expressivos: as indústrias têxteis (F. G. Bier, Companhia Fiação e Tecidos Porto Alegrense, A. J. Renner \& $\mathrm{Cia}$ ); as empresas relacionadas à fabricação de móveis (Walter Gerdau'27, Caetano Fulginiti, José Sanguinetti, D. Collin, Arnt, Depperman \& Cia); fábricas de chapéus (Kessler \& Cia, Oscar Teichmann \& Cia) e de pregos (João Gerdau); perfumaria, sabão e velas (Victor Fischel, Campani \& Cia., L. P. Barcellos \& Cia); cervejas (cervejarias Becker, Bopp e Ritter \& Filhos); doces (Ernesto Neugebauer); serrarias (Fortunato Travi, Hüber \& Müller, Santo Meneghetti, Jacob Friedrich $^{28}$, Otto Kuhn, Irmãos Elly, Serraria Garibaldi); balanças (Guilherme N. Filho); vidros (Cia de Vidros Sul Brasileira de propriedade de Martin Hogsdedt ${ }^{29}$ ); metalúrgicas (Mabilde ${ }^{30}$ \& Cia, Alberto Bins, Edgar Booth e Francisco Clausen, Alcaraz \& Cia, Só Filhos, José Becker \& Irmão, Jacques Maas, Cypriano Micheletto \& Irmão, Otto Outeiral, Bromberg \& Cia, Guilherme Knack e João R. Alves), entre outros.

No recenseamento do estado do Rio Grande do Sul do ano de $1920^{31}$, notei que a capital concentrava a maior parte das indústrias metalúrgicas (fogões, cofres, pregos, fechaduras, fundições...), das fábricas de roupas e chapéus, e de mármore do estado, totalizando duzentos e vinte e um estabelecimentos industriais dos mil setecentos e setenta e três registrados naquele momento, quase $12,5 \%$ do total de estabelecimentos. Esse percentual pequeno de indústrias concentradas em Porto Alegre em relação ao interior do estado se deve ao grande número de estabelecimentos ligados à atividade agrária, entre os quais destaco os seguintes: arreios e artigos de selaria (88), carros e carroças (39), calçados (96), fumos, charutos e cigarros (47), curtumes (77), serrarias (334), enxadas, foices e outras ferramentas (30), olarias (152), moagem de cereais (61) e moagem e torrefação de café (63).

Em outro relatório do mesmo ano, relativo ao $4 .^{\circ}$ Distrito ${ }^{32}$, percebi a importância das indústrias de móveis e de tecidos naquela região, empregando, respectivamente, duzentos e cinquenta e um, e mil e quarenta e sete trabalhadores. A fábrica de doces de Ernesto Neugebauer também se destaca no quesito mão de obra empregada, com duzentos e vinte funcionários. No mesmo relatório, notei que a jornada de trabalho nos estabelecimentos daquela região variava entre oito e doze horas, sendo que quase $75 \%$ possuíam uma jornada de nove horas e quase $12 \%$ adotavam jornadas superiores a isto.

25 REICHEL, Op. cit., 1978, p. 262.

26 RECENSEAMENTO INDUSTRIAL DO BRASIL 1920 (1925). Rio de Janeiro, Tipografia de Estatística.

27 Sobre os Gerdau, ver: FLORES, Hilda. As empresas de João Gerdau, Porto Alegre: Gerdau, 1980, p. 106; e MARCOVITCH, Jacques, Op. cit., p. 273.

28 Jacob Friederichs possuía uma serraria, fundada em 1888, que funcionava à Rua Voluntários da Pátria.

29 A fábrica da Companhia de Vidros Sul-Brasileira foi estabelecida em 1892. Martin Hogsdedt, diretor do estabelecimento, era de nacionalidade sueca e veio para o Brasil em 1885.

30 Sobre o Estaleiro Mabilde ver: MABILDE, Adriano Ballejos. Estaleiro Mabilde: as relações com os funcionários e o estado (1896-1943). Dissertação (Mestrado em História), Porto Alegre: PUCRS, 2009.

31 Por questão de espaço, retirei esta e outras tabelas que constavam no original e mantive apenas as análises. (Consultar as tabelas em minha tese de doutorado já citada). FUNDAÇÃO INSTITUTO BRASILEIRO DE GEOGRAFIA E ESTATíSTICA. Séries estatísticas retrospectivas. Rio de Janeiro: IBGE, v. 1, 1986, p. 4-8. Disponível em: http://biblioteca.ibge.gov.br/visualizacao/livros/liv17983_v1.pdf

32 Relatório da Subintendência do Quarto Distrito, apresentado ao intendente José Montaury de Aguiar Leitão em 1920. Arquivo Histórico de Porto Alegre. Sobre o 4. ${ }^{\circ}$ Distrito, ver: FORTES, Op. cit., 2004. 
A influência do capital comercial, proveniente da região da Depressão Central do estado no desenvolvimento econômico de Porto Alegre, fez com que este patronato fosse composto por um significativo número de teutodescendentes ou mesmo de imigrantes alemães. Em levantamento que realizei sobre a origem do patronato porto-alegrense, verifiquei que, entre os proprietários de estabelecimentos industriais e comerciais da cidade, havia muitos alemães, como Guilherme Becker, Bernardo Sassen, Ernesto Neugebauer, J. Aloys Friederichs, Jacob Friederichs, Martin Bromberg, João Pabst, Victor Fischel e Oscar Teichmann; alguns filhos de alemães, entre eles Alberto Bins, João e Hugo Gerdau, e Henrique Waldemar Ritter; e alguns netos de alemães, como Affonso Selbach, Antônio Jacob Renner e Walter Gerdau. Havia, ainda, proprietários de outras nacionalidades, como os espanhóis Raphael Arbos e José Salvador e o sueco Martin Hogsdedt. Na mesma linha, Pesavento afirma que Porto Alegre, no começo do século XX, "ostentava várias casas comerciais cujos proprietários eram alemães ou de origem: Menke, Wiedmannn, Félix Kessler, Folzer, Pietzker, Gertum, Steenhage, Luchsinger, Muradt, Warncke e Doerken, Schmitt, Lüderitz eram os novos nomes que vieram somar-se aos tradicionais luso-brasileiros". ${ }^{33}$ Lagemann também salienta que o elemento imigrante foi pioneiro "na produção de tecidos, banha de porco, conservas, bebidas, doçaria, madeiras, couros, máquinas, tabaco, vidros, papel, fósforos e produtos químico-farmacêutico" 34 , apesar de "não pode[r] ser atribuída [ao imigrante] a exclusividade da implantação da indústria no RS, mas apenas sua afirmação e diversificação". ${ }^{35}$ Em relação a Porto Alegre, Pesavento sublinha a relevância do imigrante alemão igualmente no comércio da capital, enfatizando ainda, como já foi dito, a influência do capital comercial no desenvolvimento industrial da cidade, diferenciando-o do restante da industrialização nacional, mais vinculada ao capital agrário. Segundo a autora,

\begin{abstract}
a importância do comércio alemão já se fez notar por ocasião da fundação da Praça do Comércio de Porto Alegre, em 1858 (Heizen e Ebert). Já em 1878, dos seus 146 membros, 37 eram de origem alemã (Heizen, Ebert, Haag, Wolkmann, Schilling, Haenzel, Ter Brüggen, Fraeb, Holtzweissig, Hirch, Folzer, Becker, Bastian, Bins, Bier, Dauth, Christoffel, Daiken, Dexheimer, Issler, Pettersen Wallau etc.). ${ }^{6}$
\end{abstract}

Em 1911, a lista de diretores da Praça do Comércio ${ }^{37}$ contava com diversos nomes da comunidade germânica, entre eles: Arthur Bromberg (vice-presidente), Franz Reimer, Theobaldo Francisco Xavier Friederichs (tesoureiro), F. G. Bier, Theodor Jacobi, Leopoldo Dexheimer, Arthur Mundt e João Patzel. Completavam a lista Hemetério Mostardeiro (presidente), João Henrique Aydos (primeiro secretário), Frederico Gomes (segundo secretário), Herminio de Almeida, Augustin Fernandes, José Barbará, Mario Amaro da Silveira, Honório Brito e Antonio Chaves de Barcellos Filho. ${ }^{38}$

33 PESAVENTO, Sandra. De como os alemães tornaram-se gaúchos pelos caminhos da modernização. In: MAUCH, Cláudia; VASCONCELOS, Naira (org.). Os alemães no sul do Brasil: cultura, etnicidade e história. Canoas: Ulbra, 1994, p. 201.

34 LAGEMANN, Eugênio. Imigração e Industrialização. In: DACANAL, José H.; GONZAGA, Sérgius (org.). RS: imigração e Colonização. 2. ed., Porto Alegre: Mercado Aberto, 1992, p. 118.

35 LAGEMANN, Op. cit., 1992, p. 127.

36 PESAVENTO, Sandra Jatahy. In: DACANAL, José H.; GONZAGA, Sérgius (org.). Op. cit., p. 163.

37 Fundada em 1857, a Praça do Comércio de Porto Alegre era uma sociedade civil, com personalidade jurídica, sendo o órgão autorizado do comércio da capital do Rio Grande do Sul.

38 LLOYD'S, Op. cit., 1913, p. 819. 
A presença significativa de teutos na economia porto-alegrense pode ser percebida nos mais variados setores. No ramo metal mecânico, nota-se a importância de empresas como Klüve e Müller, Alberto Bins, Joseph e Nicolau Becker, Emmerich Berta, Guilherme Knack, Guilherme Bostelmann, Germano Ullner, Francisco Klaus, Johan Gerdau, Pedro Wallig, Samuel Uhr, Waldomiro Schapke, Hans Lindau, Armando Martau, Scerneling e Hertzfeldt. ${ }^{39}$ Na produção de bebidas, evidencia-se o mesmo: “Bopp, Sassen, Ritter, Christoffel, Bohrer, Volkmer, Voight e Hack, Luebb, Lippert, Lackmann e muitos outros dariam contorno absolutamente alemão para o setor cervejeiro da indústria porto-alegrense". ${ }^{40}$

É interessante observar igualmente as relações existentes entre os membros do patronato porto-alegrense de origem germânica, que contribuíram para a sua constituição como classe, tanto do ponto de vista empresarial quanto no que se refere às ligações entre as famílias por intermédio do casamento. Referindo-se às associações étnicas formadas por alemães, Gertz esclarece que "as lideranças dessas instituições muitas vezes conclamavam a população a não casar com pessoas de outra etnia, a não abandonar sua língua, a não se 'meter em política', pois o envolvimento político era considerado um dos mais perigosos elementos para a perda da 'germanidade"'. ${ }^{41}$ Notadamente, essas associações tinham o objetivo de evitar que os emigrantes perdessem seus vínculos culturais e econômicos com seu país de origem. Além disso, acrescento, o fortalecimento de tais vínculos - especialmente na elite econômica do estado - favorecia sua inserção econômica na região. Desse modo, destaco alguns casamentos no seio desta elite alemã: Henrique Valdemar Renner casou-se com Paulina Kessler; sua sobrinha-irmã, Elizabeth Renner, casou-se com Guilherme Becker e, após a morte dele, com Bernard Oswald Sassen; sua irmã, Elizabeth Ritter Trein, casou-se com Christian Jacob Trein; sua filha, Catarina Trein, casou-se com Frederico Mentz; Frederico Augusto Ritter casou-se com sua prima Olga Ritter; Hugo Gerdau, filho mais velho de João Gerdau, casou-se com Ottília Bins, irmã de Alberto Bins; Helda Gerdau, filha de João Gerdau, casou-se, em 1930, com Curt Johanpeter; etc.

Tais casamentos podem ser interpretados como uma estratégia de sobrevivência e ascensão no sistema de relações sociais e econômicas vigente na cidade, como "arranjos" familiares que tinham também por finalidade acumular e preservar o capital social dentro de uma rede de relações mais estrita. Capital esse que poderia ser convertido, posteriormente, em capital econômico. Bourdieu define capital social como

o conjunto de recursos atuais ou potenciais que estão ligados à posse de uma rede durável de relações mais ou menos institucionalizadas de interconhecimento e de inter-reconhecimento ou, em outros termos, à vinculação a um grupo, como conjunto de agentes que não somente são dotados de propriedades comuns (passíveis de serem percebidas pelo observador, pelos outros ou por eles mesmos), mas também são unidos por ligações permanentes e úteis. ${ }^{42}$

O autor enfatiza a questão da utilidade prática dos relacionamentos e a possibilidade de que haja a conversibilidade desse capital social em outros tipos de ca-

39 PESAVENTO, Op. cit., 1994, p. 201.

40 PESAVENTO, Op. cit., 1994, p. 201.

41 GERTZ, René. A construção de uma nova cidadania. In: MAUCH, Cláudia; VASCONCELOS, Naira (org.). Os alemães no sul do Brasil: cultura, etnicidade e história. Canoas: Ulbra, 1994, p. 30.

42 BOURDIEU, Pierre (1980). O capital social - notas provisórias. In: NOGUEIRA, M. A.; CATANI, A. (org.). Pierre Bourdieu: escritos de educação. Petrópolis: Vozes, 1998, p. 67. 
pital, os quais possam significar, por exemplo, acesso direto a recursos econômicos (empréstimos subsidiados, informações de negócios, mercados protegidos), contatos com especialistas ou com pessoas cultas, e filiação a instituições políticas e/ou sociais. Assim, os casamentos representam oportunidades de ascensão ou manutenção de posição social. Um exemplo para o caso específico aqui examinado: ao analisar as razões da indicação de Alberto Bins para o Legislativo Federal, um documento manuscrito de 1924, citado por Gertz, afirma que ele era "um bom militante do catolicismo" e seu nome satisfazia "tanto o elemento católico como o protestante germânico, tanto o comércio quanto a indústria e a lavoura". Bins agradaria ao protestantismo germânico em virtude do fato de sua irmã, Ottília Bins, ser casada com o luterano Hugo Gerdau. ${ }^{43}$ Os relacionamentos pessoais, familiares e étnicos acabavam convertidos, enfim, para o campo econômico. Nesse sentido, Flores especula que João Gerdau, o qual havia possuído negócios de comercialização privada de terras para fins de colonização com Manoel Py na Colônia de Santo Ângelo, obteve, por intermédio deste último, informações privilegiadas a respeito das dificuldades da Cia. Fábrica de Móveis, que teve Py como um de seus liquidantes. ${ }^{44}$

Além das relações familiares, as empresas de propriedade de alemães e teuto-brasileiros também se associavam entre si, gerando diversas inversões de capital e uma diversificação das suas aplicações. Um bom exemplo desse fenômeno e das ligações propriamente econômicas estabelecidas entre os membros da comunidade germânica é a empresa Bromberg \& Cia. De propriedade de Martin Bromberg, figurava entre as mais antigas e importantes do Rio Grande do Sul. Possuía casas comerciais em Rio Grande, Pelotas, Santa Maria, Uruguaiana, Passo Fundo e Porto Alegre, e filiais no Rio de Janeiro, em Buenos Aires e em Montevidéu. A empresa importava ferragens, ferro bruto, maquinismos para toda a sorte de indústrias, arame, máquinas para agricultores, cimento, tintas, cevada e lúpulo para cervejarias e outros materiais para uso de fábricas diversas. Realizava, ainda, investimentos em fábricas de tijolos, plantações de arroz e serrarias, instalações elétricas e outras de força e luz. Meu interesse, contudo, consiste em suas associações com empresários de origem germânica como, por exemplo: Oscar Teichmann, dono de uma fábrica de chapéus; as casas “João Day, Bromberg \& Cia., importadores; Luiz Noelcher \& Cia., negociantes a varejo, de ferragens, utensílios sanitários e caseiros; O Cilindro, importadores de máquinas de costura, utensílios para eletricidade, instalações elétricas, máquinas de escrever, espingardas e armas diversas, munições etc.; União de Ferros (Bromberg, Daudt \& Cia.), importadores de ferro bruto, aço, cobre, bronze e outros materiais, ferramentas para ferraria e materiais para construção". ${ }^{45}$ Sobre a mescla entre o familiar e o empresarial, Pesavento ressalta:

Christian Jacob Trein e seu cunhado Henrique Ritter Filho eram sócios não apenas numa casa comercial em Caí, mas também na cervejaria que fundaram em Porto Alegre, em 1894. Trein e seu genro, o comerciante Frederico Mentz, montaram, por sua vez, um estabelecimento para refinação de banha na capital do Estado. Anton Jacob Renner, filho de comerciante proprietário de refinaria de banha, de serraria e de empresas construtoras de moinhos do Caí, tornou-se sócio da firma comercial de seu sogro, Christian Jacob Trein. Em 1911, montou uma fábrica de capas impermeáveis em Caí, com Frederico Engel [...]. Em 1916, transferiu-se

43 GERTZ, René. O Aviador e o Carroceiro: política, etnia e religião no Rio Grande do Sul dos anos 1920. Porto Alegre: EdiPUCRS, 2002, p. 56.

44 FLORES, Hilda. As empresas de João Gerdau. Porto Alegre: Gerdau, 1980, p. 99; e MARCOVITCH, Op. cit., 2005, p. 273.

45 LLOYD’S, Op. cit., 1913, p. 819-820. Ver também: PESAVENTO, Op. cit., 1994, p. 201. 
para Porto Alegre, estabelecendo-se com a empresa de fiação e tecelagem que daria surgimento ao conglomerado das Indústrias Renner. Adolpho Carlos Oderich, depois de trabalhar como caixeiro-viajante de uma casa comercial em Porto Alegre, abriu seu próprio negócio de importação de fazendas em Caí e, em 1908, juntamente com outros comerciantes, montou uma fábrica de banha no município de Canoas. ${ }^{46}$

Observo, assim, as interligações entre os laços econômicos e os laços de amizade e parentesco que se entrecruzavam e se complementavam. Por conseguinte, os mesmos nomes, os mesmos patrões são identificados em diversos espaços sociais: nos lares, nos clubes sociais e esportivos ${ }^{47}$ e, é claro, nos investimentos econômicos. Para o que me interessa neste artigo, eles também se encontram na constituição de uma efetiva classe patronal que, diante das reivindicações e mobilizações do operariado (o qual, é preciso lembrar, também contava com diversos elementos de origem teuta), precisou se organizar e se unificar.

Desse modo, percebi que, apesar do predomínio de pequenos estabelecimentos com baixíssima utilização de tecnologia e pouca quantidade de empregados, a cidade contava também com um significativo número de grandes empresas, com emprego de maquinário moderno para a época e aproveitamento de significativa mão de obra. Muitos dos sócios ou proprietários desses estabelecimentos eram de origem teuto-brasileira. A seguir, analisarei as estratégias adotadas pelo patronato no enfrentamento com o operariado nos momentos de greve, as quais, dialeticamente, contribuíram para a constituição da classe patronal.

\subsection{Estratégias patronais}

Após esta concisa apresentação do patronato da capital do estado no início do século XX, irei abordar as estratégias por ele adotadas durante os embates com os operários ao longo das greves aqui examinadas. Devo ressaltar que as práticas utilizadas pela burguesia representam estratégias de conservação/sucessão e têm como finalidade a preservação do status quo e de suas posses materiais. Pretendo, nesse âmbito, e ainda que de forma breve, tratar do processo de organização classista do patronato, do "fazer-se" da classe patronal. Como mencionei no início deste capítulo, darei especial ênfase à greve generalizada de 1919, visto que a pauta de reivindicações dos trabalhadores era direcionada preferencialmente aos patrões.

Tanto a greve de 1917 quanto a de 1918, como demonstrei no primeiro capítulo de minha tese de doutorado ${ }^{48}$, foram greves gerais deflagradas por associações operárias que reuniam diferentes sindicatos classistas e que reivindicavam a legitimidade de representar seus interesses diante de determinados interlocutores (estado e patrões). Foram, portanto, movimentos mais unificados e homogêneos que a greve de 1919, a qual pode ser considerada uma greve "eruptiva" — utilizando a expressão de Perrot -, na verdade uma sucessão de greves que se desencadeavam simultaneamente, sem uma coordenação conjunta. Tais movimentos ocorriam como erupções do magma em ebulição, difundindo-se como uma epidemia. Perrot denominou greves desse tipo de "eruptivas", pois ocorrem como se

46 PESAVENTO, Op. cit., 1994, p. 202.

47 SILVA, Carolina Fernandes da. O Remo e a História de Porto Alegre, Rio Grande do Sul: mosaico de identidades culturais no longo século XIX. Dissertação (Mestrado em Ciências do Movimento Humano), Porto Alegre: UFRGS, 2011.

48 QUEIRÓS, Op. cit., 2012. 
estivessem "possuídas por uma força exterior, irresistível”. ${ }^{49} \mathrm{E}$, de fato, as paralisações de 1919 se sucediam de modo quase que incontrolável: cada vitória de uma categoria impulsionava as reivindicações de outras, e assim sucessivamente. Ou seja, as greves gerais dos anos anteriores irromperam a partir do chamamento de associações operárias que centralizavam e conduziam as ações coletivas de seus sindicatos associados. Na greve geral de 1917, foi criada a Liga de Defesa Popular (LDP), um comitê com a participação dos anarquistas e dos pedreiros sindicalistas, que, no decorrer do movimento paredista, converteu-se em uma espécie de centro diretor do movimento. Do mesmo modo, em 1918, a greve foi convocada por três associações operárias - Federação Operária do Rio Grande do Sul (FORGS), União Geral do Trabalhadores (UGT) e União Metalúrgica -, que representavam os interesses dos trabalhadores paredistas. Em 1919, como as exigências dos operários eram encaminhadas diretamente ao patronato, sem a intermediação do estado, o conflito de classes tornou-se mais agudo. A escalada dos movimentos ocorridos durante esse ano - em sua maioria, vitoriosos - fez com que as mobilizações de setembro se radicalizassem. Durante o movimento paredista, o subchefe da polícia da 1. ${ }^{a}$ região, Dr. Eurico Lustoza, mandou organizar uma estatística dos operários paralisados ${ }^{50}$, que discriminava o número de grevistas em cada uma das empresas pesquisadas. No quadro, observei a grande quantidade de padarias que aderiram à greve, 14 estabelecimentos, totalizando cento e setenta e quatro trabalhadores paralisados. Percebi que algumas padarias possuíam mais de vinte operários parados: a Padaria Feliz, com vinte e oito; a Padaria Popular, com vinte e dois; e a Padaria Varsóvia, com vinte. Outro ramo com significativa participação foi o têxtil, com um total de oitocentos e sessenta e seis operários em greve. Se fossem somados os empregados do setor têxtil com os da Cia Força \& Luz, daria um total de 65,94\% dos operários acima relacionados. Devo observar, contudo, que o quadro omite importantes categorias em greve, como os carpinteiros, os sapateiros, os alfaiates e os operários do ramo metalúrgico, por exemplo. Segundo o Correio do Povo, cerca de seiscentos metalúrgicos teriam aderido ao movimento ${ }^{51}$, o que elevaria o número de grevistas para três mil, demonstrando a força daquele movimento.

\subsubsection{Vitórias operárias, demissões, participação política e lockouts}

A partir de maio de 1919, movimentos grevistas rebentaram em muitos estabelecimentos da capital. Antes, em abril, eclodiu uma greve dos operários que trabalhavam nas obras do cais. ${ }^{52}$ Esta durou até o início de julho, quando os patrões propuseram um aumento de $1 \$ 000$ (mil réis) para os operários da serraria e $5 \$ 000$ (cinco mil réis) para os que trabalhavam no cais propriamente dito, e mais sete dias de salário a título de gratificação..$^{53} \mathrm{Em}$ maio, trapicheiros e estivadores também aderiram à paralisação. Segundo O Syndicalista, em poucos dias, a categoria retornou vitoriosa ao trabalho. ${ }^{54}$ No mesmo mês, o Sindicato de Resistência dos Alfaiates deflagrou uma greve geral da categoria. ${ }^{55} \mathrm{~A}$ mobilização durou oito

49 PERROT, Op. cit., 1984, p. 35-36. Tradução minha. (A referência completa não foi citada anteriormente.)

50 Correio do Povo, Porto Alegre, 06 set. 1919, p. 3.

51 Correio do Povo, Porto Alegre, 18 jul. 1919, p. 4.

52 O Syndicalista, Porto Alegre, 27 maio 1919, p. 2.

53 O Syndicalista, Porto Alegre, 01 maio 1919, p. 3.

54 Idem.

55 O Syndicalista, Porto Alegre, 01 maio 1919, p. 4. 
dias, até que os proprietários das alfaiatarias apreciassem uma nova tabela de preços elaborada pelo sindicato, que foi posteriormente atendido em suas reivindicações. ${ }^{56}$

Ainda no mês de maio, o Sindicato Padeiral declarou-se em greve, postulando que fossem postos em liberdade os padeiros presos na greve anterior e que uma comissão de higiene fiscalizasse as padarias mensalmente..$^{57}$ Este sindicato também foi bem-sucedido em suas reivindicações. ${ }^{58}$ No final de julho, o Sindicato dos Operários em Calçados proclamou-se em greve, exigindo aumento de $25 \%$ nos ordenados e redução da jornada de trabalho. ${ }^{59}$ De acordo O Syndicalista, vários proprietários já teriam cedido às intenções dos grevistas, entre eles: Fábrica Castor, Sapataria Pontual, Casa Condor, A Pontualidade, Bota de Ouro, Jacinto Pandolpho, Botinha de Ouro, Sapataria Roma, Pedro Mansur, Theobaldo Klein, João Martineli, J. Buanove, Maximílio Ouriques, Arthur Hultsch, E. Lima e Cia., Gustavo Hartz, Frederico Strassburger, Avelino Freitas, Alcides Ignácio Moreira e Francisco Brino. ${ }^{60}$

Uma estratégia desenvolvida pelos proprietários de certos estabelecimentos com o objetivo de desestimular os operários a aderirem aos movimentos paredistas e de garantir a continuidade da produção era substituir os trabalhadores em greve. Segundo Sirot, durante as greves, "a necessidade de manter a produção, reduzida ou suspensa pela greve, se impõe. A maneira mais elementar e a mais direta consiste na contratação de novos trabalhadores". ${ }^{61}$ E em 1919, esse foi um artifício bastante recorrente por parte do empresariado. A diretoria da Cia. Força e Luz, por exemplo, "havia conseguido contratar vários maquinistas e foguistas licenciados da armada que aqui se achavam e que deram começo ao trabalho de aquecimento das caldeiras da usina", contratando também em São Paulo "pessoal para trabalhar na sua usina, o qual [tinha] embarcado pela estrada de ferro com destino a essa capital". ${ }^{62}$ A mesma Companhia publicou uma série de anúncios nos quais oferecia empregos a maquinistas e foguistas interessados em substituir os grevistas. ${ }^{63} \mathrm{~A} \mathrm{em}-$ presa, ainda, divulgou na imprensa e afixou o seguinte aviso nas suas portas:

Previne-se aos empregados desta companhia que, dentro do prazo suficiente para o conhecimento deste aviso, serão os mesmos considerados despedidos e substituídos caso não se apresentem para assumir os seus lugares.

Os retardatários que alegarem moléstia ou força maior serão readmitidos, desde que suas alegações forem plenamente justificadas.

Aqueles que se demonstrarem desafetos [sic] à companhia, perturbando o serviço e a disciplina serão em tempo demitidos. ${ }^{64}$

No ano anterior, quando ocorrera a interrupção do fornecimento de energia elétrica em virtude da paralisação dos operários que trabalhavam na usina da

56 O Syndicalista, Porto Alegre, 27 maio 1919, p. 2. Neste número d'O Syndicalista encontra-se a tabela apresentada pelos alfaiates e um boletim da categoria. A tabela foi transcrita em minha tese de doutorado. Ver também: Gazeta do Povo, Porto Alegre, 15 maio 1919, p. 2. Até o início de junho, apenas "os srs. João Meneghetti e Sassen não haviam dado a definitiva resposta que, entretanto, sabia-se satisfatória". Gazeta do Povo, Porto Alegre, 06 jun. 1919, p. 3.

57 O Syndicalista, Porto Alegre, 01 maio 1919, p. 3. Esta greve foi abordada no capítulo III de minha tese de doutorado.

58 Gazeta do Povo, Porto Alegre, 26 maio 1919, p. 3.

59 Correio do Povo, Porto Alegre, 29 ago, 1919, p. 4.

60 O Syndicalista, Porto Alegre, 02 ago 1919, p. 3.

61 SIROT, Op. cit., 2002, p. 207.

62 A Federação, Porto Alegre, 05 set. 1919, p. 5. Ver também: Correio do Povo, Porto Alegre, 05 set. 1919, p. 5.

63 Correio do Povo, Porto Alegre, 05 set. 1919, p. 1.

64 A Federação, Porto Alegre, 06 set. 1919, p. 5. 
Companhia Força \& $\mathrm{Luz}^{65}$, o presidente do estado ordenou o restabelecimento do serviço, promovendo a ocupação militar do estabelecimento ${ }^{66}$ e enviando alguns homens que estavam recolhidos nas prisões do $1 .^{\circ}$ e $3 .^{\circ}$ distritos para substituírem os grevistas. ${ }^{67} \mathrm{O}$ socorro ao patronato por parte do estado, ao convocar indivíduos reclusos para trabalharem no lugar de operários grevistas, foi recorrente em outros movimentos paredistas ocorridos no período.

Outras empresas também vinham demitindo sistematicamente os empregados grevistas como, por exemplo, a Padaria Varsóvia, de propriedade de Carlos Tropowski, que já havia dispensado todos os seus funcionários - em número de vinte, segundo o Correio do Povo, e de quarenta, segundo manifesto da União Maximalista ${ }^{68}$ - e a sapataria de Mendelski que, "no afã de sua cólera divina despediu todos os seus empregados 40 homens". ${ }^{69}$ A Companhia Telephônica (empresa Ganzo, Durruty \& C) adotou a mesma postura e, no dia 4 de setembro, demitiu os vinte e um operários que se achavam parados, declarando encerrada a greve naquela empresa. ${ }^{70} \mathrm{~A}$ mesma companhia já havia demitido, no final de agosto, dois operários "por pertencerem ao sindicato daquela empresa" 71 , e feito circular boletins informando que a empresa dispensaria mais quinze empregados "pelo mesmo motivo"72. Em editorial escrito por Carlos Bonhomme e intitulado Motivos justificados, resolução injusta, o Correio do Povo criticou a decisão da Companhia de demitir os empregados, frisando a justeza de suas reclamações e os inconvenientes que tal atitude poderia provocar ao comércio e aos assinantes em geral. ${ }^{73}$

No movimento grevista de 1917, recorreu-se à idêntica estratégia. Mesmo que, nesta greve, o estado tenha atuado no sentido de atender o que fora pleiteado pelos grevistas e propalado fazer a "incorporação do proletariado à sociedade moderna", os patrões não se mostraram propensos a repetir o "exemplo" fornecido pelo governo. Um exemplo disso é que, na fábrica de meias da Cia. Fabril Porto Alegrense, mandou-se "prevenir aos grevistas em suas residências que haviam sido dispensados de seus serviços na fábrica"74 e, logo em seguida, foram contratados outros funcionários. Observei que essa estratégia patronal de troca de empregados grevistas por outros trabalhadores podia carregar consigo o ônus de promover uma radicalização dos embates com o operariado, uma vez que tal atitude era moralmente rechaçada por não coadunar, na opinião dos militantes, com o repertório de "armas" de uma "greve limpa”. Desse modo, vi, por exemplo, que, em virtude do aviso veiculado pela Cia. Força e Luz, houve o atentado à bomba na sede da companhia 75 , enquanto que os operários admitidos para substituírem os grevistas na Cia. Fabril Porto Alegrense eram "constantemente ameaçados pelos grevistas que pretendem até proibi-los de trabalhar". ${ }^{76}$ Apesar disso, diversas outras empresas dispensaram sem nenhuma relutância os operários que quiseram aderir à greve. Entre eles, as dos srs. J. Ayres Friedrich, F. C. Kessler, Oscar Teich-

65 A Federação, Porto Alegre, 22 jul. 1918, p. 6.

66 A Federação, Porto Alegre, 22 jul. 1918, p. 6.; Correio do Povo, Porto Alegre, 23 jul. 1918, p. 6.

67 Correio do Povo, Porto Alegre, 23 jul. 1918, p. 4.

68 Correio do Povo, Porto Alegre, 06 jul. 1919, p. 1 e Ao Povo Sedento de Liberdade. União Maximalista. Anexo 9. In: ESTADO DO RIO GRANDE DO SUL. Processo-Crime n. ${ }^{\circ}$ 1.016, Porto Alegre, 1919, p. 20.

69 Ao Povo Sedento de Liberdade. União Maximalista. Anexo 9. In: ESTADO DO RIO GRANDE DO SUL. Processo-Crime n ${ }^{\circ}$ 1.016, Porto Alegre, 1919, p. 20.

70 Correio do Povo, Porto Alegre, 05 set. 1919, p. 5.

71 Gazeta do Povo, Porto Alegre, 29 ago. 1919, p. 3.

72 Idem.

73 Correio do Povo, Porto Alegre, 07 set. 1919, p. 1.

74 ESTADO do Rio Grande do Sul. Arquivo Público do Estado. Processo-Crime n. ${ }^{\circ} 833$. Porto Alegre: 1917, p. 77.

75 Correio do Povo, Porto Alegre, 07 set. 1919, p. 10.

76 ESTADO do Rio Grande do Sul. Arquivo Público do Estado. Processo-Crime n. ${ }^{8}$ 833. Porto Alegre: 1917, p. 21. 
mann e Cia., Kessler e Vasconcelos e Walter Gerdau. ${ }^{77}$

A estratégia de demissão e substituição de operários em greve não se limitava, é claro, apenas ao patronato porto-alegrense. Em outras cidades do estado, lançou-se mão com frequência do mesmo recurso. Por exemplo: durante a greve dos estivadores, ocorrida no ano de 1919, na cidade de Pelotas, as autoridades "obrigaram uns infelizes presos a trabalharem a bordo dos navios em substituição dos estivadores que se acham em greve, reclamando as justas oito horas de trabalho e aumento de salário". ${ }^{78}$ Isso também teria ocorrido em Rio Grande, na greve daquele ano, quando "os presos que se acham recolhidos no segundo posto fizeram o serviço de descarga de carvão para a Usina Elétrica"79. Para a imprensa operária, o governo do estado fazia "exatamente como [...] a Alemanha com os prisioneiros de guerra", denunciando, ainda, que a "polícia a serviço do burguês não escolhe os meios. Transforma os presos em escravos". .0

Outra estratégia do patronato diante das ações coletivas dos operários era recorrer ao estado, a fim de buscar apoio e garantia para a "liberdade de trabaIho". Por essa razão, a identificação feita pelos trabalhadores entre estado e burguesia se torna compreensível. O primeiro foi, inúmeras vezes, convocado para intermediar as divergências de interesse existentes entre as duas classes. No entanto, "esta mediação dos conflitos entre patrões e operários pelo Estado jamais é desinteressada: sua primeira preocupação é a contenção da agitação". ${ }^{81}$ Um exemplo do comportamento do patronato em solicitar auxílio do governo verifica-se no decorrer das greves de setembro de 1919, quando os proprietários e diretores de estabelecimentos cujos operários estavam paralisados dirigiram-se ao presidente do estado, a fim de mostrar-Ihe a situação aflitiva pela qual passava a indústria local e solicitar-Ihe providências. Dirigiram-lhe, ainda, um relatório com o objetivo de "Ihe provar a situação precária em que ficaria a indústria se concedesse as exigências dos grevistas". ${ }^{82}$

A despeito de a burguesia industrial ser, naquele momento, uma fração não hegemônica da classe dominante no Rio Grande do Sul, a tomada de algumas posições no campo político passou a ser uma alternativa para fortalecer suas posições no âmbito econômico e proteger seus interesses. Ou seja, parecia ser insuficiente a esta elite usufruir o poder econômico; ela precisava também alcançar posições político-institucionais, a fim de obter "os meios principais do exercício do poder, de adquirir e conservar riqueza, e de configurar as principais vantagens do prestígio". 83 Nesse sentido, é necessário compreender os mecanismos que levaram esse privilegiado grupo econômico a fazer a passagem de um campo ao outro. Mills afirma que, normalmente, as mesmas pessoas que "[...] governam as grandes empresas, governam o aparelho do Estado e exigem as suas prerrogativas, [...] ocupam os postos de comando na estrutura social nos quais estão centrados agora os instrumentos efectivos do poder e a riqueza e a celebridade de que gozam". ${ }^{84}$

77 O Syndicalista, Porto Alegre, 03 set. 1919, p. 1.

78 Aos Trabalhadores. Anexo 23. ESTADO do Rio Grande do Sul. Arquivo Público do Estado. Processo-Crime n. ${ }^{\circ} 1016$, Porto Alegre: 1919.

79 O Syndicalista, Porto Alegre, 27 maio 1919, p. 1.

80 O Syndicalista, Porto Alegre, 27 maio 1919, p. 1.

81 SIROT, Op. cit., p. 234.

82 A Postos Operários - Manifesto da FORGS. 04 set. 1919. Anexo 15. In: ESTADO DO RIO GRANDE DO SUL. Processo-Crime n. ${ }^{\circ}$ 1.016, Porto Alegre, 1919.; Correio do Povo, Porto Alegre, 03 set. 1919, p. 5.

83 MILLS apud CORADINI, Odaci L. Engajamento associativo-sindical e recrutamento de elites políticas: tendências recentes no Brasil. Revista de Sociologia e Política, v.28, 2007, p. 195-217.

84 MILLS, C. W. La Elite del Poder. México: Fondo de Cultura Económica, 1957, p. 11-12. 
Os membros da elite econômica da capital foram sendo recrutados pelo partido então hegemônico — o PRR — para suas fileiras, e empresários como Alberto Bins começaram a exercer um papel efetivo em termos de participação nas políticas públicas. Bins foi eleito conselheiro municipal em 1908; representante na Assembleia Estadual em 1913, 1917, 1921 e 1926; vice-intendente em 1924 e intendente municipal em $1928 .{ }^{85}$ Teria sido conduzido à esfera política por intermédio do próprio Júlio de Castilhos. ${ }^{86}$ Em entrevista concedida a Erich Fausel, autor de uma biografia sua, Bins afirmava que a "firme convicção de ser um representante da classe produtora reg[ia] toda a sua atuação administrativa e política" ${ }^{87}$, o que corrobora o fato de que representantes da burguesia industrial passaram a aproximar-se - e participar - do estado como forma de fazerem valer seus interesses econômicos. Outros exemplos dessa dinâmica: nas eleições municipais de 1920, José Sanguinetti, proprietário de uma fábrica de móveis, ficou entre os suplentes para o Conselho Municipal ${ }^{88}$ e, no pleito de 1924, Victor Adalberto Kessler ${ }^{89}$, filho de Felix Christiano Kessler, sócio da fábrica de chapéus Kessler \& Cia, elegeu-se conselheiro municipal com sete mil, duzentos e sessenta e um votos. ${ }^{90}$

Como foi analisado em minha dissertação de mestrado91, o governo do Rio Grande do Sul colocava-se como representante de toda a sociedade, considerando-se o impulsionador do desenvolvimento harmônico do estado por contar com "o apoio estimulante de todas as classes sociais". ${ }^{2}$ O PRR era um partido qualitativamente diferente dos demais existentes no país, por não ser composto pela elite tradicional do estado, contando com uma oposição forte e organizada..$^{93} \mathrm{Em}$ virtude disso, necessitou de um maior respaldo de outros setores sociais, abrangendo demandas diversas e promovendo uma expansão de sua base social, incluindo a burguesia industrial e comercial. Tais segmentos foram incorporados "na estruturação de um partido político, para o qual era vital a composição com os capitais emergentes". ${ }^{94}$

Com isso, grupos sociais emergentes, como o patronato comercial e industrial, passaram a ser cooptados pela estrutura do partido e, "como integrantes do aparato de hegemonia que sustentava o PRR, alguns empresários ocuparam cargos políticos de destaque no decorrer da República Velha". ${ }^{55}$ O próprio operariado também foi inserido nos quadros do PRR, bastando ver os casos de Francisco Xavier da Costa e Vigo Thompson Collin, que se tornaram conselheiros municipais. Segundo Pesavento, em Porto Alegre, maior centro industrial do estado, fazia-se notar nitidamente

a presença marcante dos empresários como conselheiros municipais: Alberto Bins e Victor Henrique Silva (fundição e metalúrgica), Antônio Chaves Barcellos Filho (lanifício e moinho), Simão Kappel, Edmundo

85 PACHECO, Ricardo de Aguiar. A Vaga Sombra do Poder: vida associativa e cultura política em Porto Alegre da década de 1920. Tese (Doutorado em História), Porto Alegre: UFRGS, 2004, p. 125.

86 Idem, p. 124.

87 FAUSEL, Erich. Alberto Bins: o merlense brasileiro. São Leopoldo: Rotermund \& Cia. Ltda., s/d, p. 12.

88 A Federação, Porto Alegre, 29 set. 1920, p. 4.

89 Em 1918, Victor Adalberto Kessler havia sido eleito por unanimidade suplente da diretoria do Banco Nacional do Commércio em Porto Alegre. Correio do Povo, Porto Alegre, 21 mar. 1918, p. 4.

90 A Federação, Porto Alegre, 03 out. 1924, p. 3.

91 QUEIRÓS, César A. B. O governo do Partido Republicano Rio-grandense e a questão social (1895-1919). Dissertação (Mestrado em História). Universidade Federal do Rio Grande do Sul, Porto Alegre, 2000.

92 MENSAGEM do Presidente do Estado à Assembleia dos Representantes. 1903, p. 8.

93 PINTO, Celi Regina. Positivismo: um Projeto Político Alternativo (RS: 1889-1930). Porto Alegre: L\&PM, 1986, p. 15.

94 PESAVENTO, Op. cit., 1988, p. 238.

95 Idem, p. 239. 
Arnt e Francisco Herzog (móveis), Carlos Júlio Becker e H. de Barros Figueiredo Jr. (calçados), Frederico Linck e Ramiro Barcellos (charqueada), Frederico Dexheimer e Victor Alberto Kessler (beneficiamento de arroz), Felipe Schmitt e Frederico Trein (banha), José Bertaso (indústria gráfica), Eurípedes Mostardeiro (arroz e fiação e tecidos), Antônio Mostadeiro Filho (interesses ligados à fabricação de papel e papelão) e os já citados Luís Englert e Domingos Martins Pereira de Souza. ${ }^{96}$

Na Assembleia dos Representantes do Estado, empresários de diferentes ramos, atuantes na capital, também ocuparam o cargo de deputado pelo PRR. Alguns exemplos: Possidônio Mâncio da Cunha Jr., ligado à Companhia Fiação e Tecidos Porto-Alegrense e com participação em várias empresas do estado, como, por exemplo, a Fiat Lux; o já referido Alberto Bins, da Metalúrgica Berta; Antônio Soares de Barcellos, proprietário de fábrica de acolchoados e um dos diretores da Fiat Lux; Antônio Chaves Barcellos Filho, do Lanifício São Pedro e da casa comercial Chaves \& Almeida; Manoel Py, da Companhia Fiação e Tecidos Porto-Alegrense; Eurípedes Mostardeiro, cuja família era incorporadora da Fiateci, entre outros. ${ }^{97}$ Observo, pois, a tentativa da burguesia porto-alegrense de se fazer representar politicamente por meio da participação nos assentos legislativos — tanto municipais quanto estaduais. Com isso, por estarem próximos ao estado, esses empresários podiam dispor de forma mais "garantida" do seu apoio quando seus empregados se declaravam em greve, como foi visto anteriormente. Outras medidas empregadas pelo patronato diante das greves aqui examinadas foram a tomada conjunta de decisões e o lockout.

No começo de agosto de 1919, foi a vez dos marceneiros, carpinteiros e classes anexas entrarem em greve. Esse movimento - o primeiro da categoria em Porto Alegre - durou doze dias e resultou na vitória dos trabalhadores ${ }^{98}$, que conseguiram não só a redução da jornada de trabalho para oito horas, mas também o aumento de $3 \$ 000$ (três mil réis) em seus salários. ${ }^{99}$ Contudo, durante a greve, já se observa a tentativa dos patrões de negociarem coletivamente com os empregados. No momento em que os operários da fábrica de móveis Arnt, Depperman \& Cia. ${ }^{100}$ solicitaram ao tenente-coronel Edmundo Arnt, sócio da empresa, a adoção da jornada de oito horas e o aumento de salário de 25\%, ele lhes declarou que "antes de dar uma resposta iria convocar uma reunião com os demais colegas a fim de que, em comum acordo, os proprietários de fábrica de móveis resolvessem sobre o assunto". ${ }^{101}$ Assim, em reunião da classe patronal ocorrida no salão nobre do clube Grêmio Náutico União, os proprietários de marcenarias enviaram a seguinte proposta aos operários:

Horário - o horário oficial será de oito horas por dia. Toda vez que em uma oficina houver trabalho fora do horário, "o operário por dia" perceberá neste caso o correspondente por hora de trabalho, sobre sua diária.

\footnotetext{
96 Ibidem, p. 241.

97 PESAVENTO, Op. cit., 1988. p. 239-240.

98 O Syndicalista, Porto Alegre. 03 set. 1919, p. 3. Sobre este movimento, Friedrich Kniestedt — que era tesoureiro do referido Sindicato - menciona que os trabalhadores em madeira tinham entrado em greve em solidariedade aos trabalhadores da indústria metalúrgica que reclamavam por uma jornada de oito horas de trabalho. GERTZ, Op. cit., 1989, p. 127.

99 RELATÓRIO do Chefe de Polícia Interino Eurico de Souza Lustosa, Porto Alegre, 1920, p. 355-357 (BPERS). 100 Fundada por Simon Kappel e Edmundo Arnt em 1869, passou a chamar-se Arnt, Depperman \& Cia. após a saída do sócio João Kappel Sobrinho, filho de Simon Kappel.

101 Correio do Povo, Porto Alegre, 06 ago. 1919, p. 4.
} 
Aumento - O aumento de salário para o "empregado por dia" consiste na diminuição do horário e para os operários em peça aumentar-se-á o preço de todos os serviços na proporção de menos para os já bem pagos, e mais para os atualmente mal pagos, não podendo este aumento ser inferior nunca a $5 \%$ e mais do que $15 \%$, a juízo dos patrões. ${ }^{102}$

As propostas foram rejeitadas pelo sindicato que, agradecendo a "esmola", decidiu pela continuidade da greve, em função de que elas "não estavam de acordo com as resoluções tomadas pelos operários". ${ }^{103}$ Em suas Memórias, Friedrich Kniestedt, um dos principais dirigentes da FORGS no período e membro do Sindicato dos Marceneiros, relata a respeito da greve: "depois de uma semana quase todas as marcenarias tinham concordado [com a redução da jornada de trabalho para oito horas], depois de duas semanas quase todas as serrarias, e mais uma semana depois também a grande fábrica de cadeiras e móveis de Gerdau concordou". ${ }^{104}$ Entretanto, as exigências foram atendidas parcialmente e os marceneiros tiveram de se contentar com as propostas dos patrões. No caso dos carpinteiros, ocorreu uma situação semelhante: alguns proprietários reuniram-se na Carpintaria Sommer (de propriedade de Roberto Sommer e sita à Rua Ernesto Alves, 71) e "resolveram conceder aos operários 8 horas de trabalho, 10\% sobre os salários e a garantia das ferramentas em caso de incêndio". ${ }^{105}$

Apesar disso, o sindicato recusou a proposta dos patrões e optou pela continuidade da greve até que todas as exigências cabalmente fossem aceitas: "Em vista desta resposta, os proprietários uniram-se e resolveram sustentar suas decisões e acordaram abrir as oficinas a fim de serem admitidos ao serviço todos os operários que queiram retornar ao trabalho. Ficou resolvido, também, que no caso de não comparecimento dos operários, as carpintarias fechassem, por tempo indeterminado". ${ }^{106}$

Essa decisão dos proprietários de carpintarias de Porto Alegre caracteriza um lockout, recurso de pressão com potencial de coagir os trabalhadores a voltarem ao serviço, sinalizando uma verdadeira "queda de braço" entre patrões e empregados: quem teria condições de resistir por mais tempo? Os patrões respondem à greve operária com uma greve patronal. ${ }^{107}$ De forma semelhante aos boicotes organizados pelos operários, o lockout também se constitui em uma técnica de pressão, nesse caso exercida pelos patrões, que se baseia na abstenção do trabalho por meio do fechamento dos estabelecimentos. Esse recurso pode ser definido como a recusa por parte dos patrões em ceder aos trabalhadores os instrumentos de trabalho necessários para a sua atividade e "é usado, na maior parte das vezes, como reação por parte dos empresários contra indicativos de greve". ${ }^{108}$ Sirot o considera um "método de resistência radical"109 empregado por "alguns

102 Correio do Povo, Porto Alegre, 12 ago. 1919, p. 4. Segundo Pesavento, "a remuneração por peça atuava como um estímulo para trabalhar mais e obter um maior salário, o que redundava, na prática, em dilatação da jornada de trabalho". PESAVENTO, Op. cit., 1988, p. 52.

103 Correio do Povo, Porto Alegre, 12 ago. 1919, p. 4. O Sindicato dos Marceneiros, Carpinteiros e Classes Anexas distribuiu um boletim intitulado Aos trabalhadores e ao Povo em geral no qual justificava a recusa da oferta dos proprietários de fábricas e oficinas. Aos Trabalhadores e ao Povo em Geral. Anexo 21. In: ESTADO DO RIO GRANDE DO SUL. Arquivo Público do Estado. Processo-Crime n. ${ }^{\circ} 1016$. Porto Alegre: 1917.

104 GERTZ, Op. cit., 1989, p. 127.

105 Correio do Povo, Porto Alegre, 12 ago. 1919, p. 4.

106 Correio do Povo, Porto Alegre, 12 ago. 1919, p. 4.

107 SIROT, Op. cit., 2002, p. 210.

108 TREU, Tiziano. Lock-Out. In: BOBBIO, Norberto (org.). Dicionário de Política. Brasília: Universidade de Brasília, 1998, p. 731.

109 SIROT, Op. cit., 2002, p. 210. 
patrões combativos ou bem organizados [...] como uma resposta, quase imediata, destinada a mostrar a sua vontade de resistir e, assim, colocar um fim rápido ao conflito". ${ }^{110}$ Segundo Treu, o lockout pode ser defensivo ou ofensivo, sendo que o objetivo comum a ambas as formas é o de "pôr o empresário numa posição mais vantajosa em relação aos trabalhadores envolvidos na disputa". ${ }^{11}$

O emprego de tal estratégia também pode ser observado em outras ocasiões: na greve dos tecelões e chapeleiros do mesmo ano, por exemplo, os proprietários das fábricas Companhia Têxtil Rio-Grandense, Companhia Fiação e Tecidos Porto-Alegrense, Companhia Fabril Porto-Alegrense, A. J. Renner \& Cia, F. C. Kessler, Eduardo Sommer e Oscar Teichmann deliberaram "fazer cessar o funcionamento" das fábricas. ${ }^{112}$ Todavia, no período aqui estudado, as ameaças de lockout foram mais comuns do que a sua aplicação.

Enfim, as principais estratégias usadas pelos patrões durante as greves abordadas, em especial na de 1919 (quando as reivindicações operárias dirigiram-se, sobretudo, a eles), foram a substituição dos operários grevistas, a ameaça ou a efetivação de lockouts, o apelo à intervenção do Poder Público (fortalecida pela participação de empresários no campo político) e a negociação coletiva dos patrões. Tais métodos sinalizam que, no processo de enfrentamento com os trabalhadores, também o patronato estava constituindo-se e organizando-se como classe.

\subsubsection{A organização patronal e suas ações conjuntas}

Em face de tamanha pressão derivada da ação organizada dos trabalhadores e de suas associações classistas, tornou-se necessário, da parte do patronato, a adoção de um conjunto de estratégias coletivas. No início do século XX, os industriais ainda não estavam reunidos em uma entidade classista, "como acontecia com os comerciantes, que desde 1858 já possuíam a Associação Comercial, ou os criadores, que haviam fundado em 1912 a União dos Criadores". ${ }^{113}$ Apesar de desprovidos de uma instituição própria, os industriais congregavam-se nas entidades associativas dos comerciantes, entre as quais se destacava a Praça de Comércio de Porto Alegre. Isso se justifica quando se considera que os interesses de ambas as frações não agrárias da burguesia - ou seja, comerciantes e industriais — apresentavam, ao menos naquele momento, mais complementaridades do que divergências.

Durante a greve geral de 1906 - a "Greve dos 21 dias" —, a fim de defender os interesses da classe patronal frente à pressão dos operários, ocorreu uma tentativa de associação da classe com o intuito de formar uma entidade específica. A iniciativa capitaneada por Alberto Bins defendia a criação de uma organização dos empresários que os habilitasse a adotar ações conjuntas no confronto com os trabalhadores paredistas. Para Bins, os industrialistas "precisavam ter um órgão legítimo e autorizado, que cuide de tudo quanto lhes diz respeito e que se entenda diretamente com os poderes públicos". 114 É sintomático observar que essa primeira iniciativa do patronato de constituir uma entidade de classe coincidiu com a fundação da FORGS, evidenciando a dialética que preside a formação das duas

\footnotetext{
110 SIROT, Op. cit., 2002, p. 211.

111 Idem, p. 732

112 Correio do Povo, Porto Alegre, 08 set. 1919, p. 3.

113 MERTZ, Marli. A burguesia industrial gaúcha e suas tentativas de organização: de sua origem a 1930. Ensaios FEE, Porto Alegre, v. 12, n.2, 1991, p. 424.

114 Correio do Povo, Porto Alegre, 07 out. 1906, p. 5.
} 
classes fundamentais do modo de produção capitalista. Schmidt salienta que "assim como a classe operária porto-alegrense procurava cristalizar a sua identidade em uma associação - a FORGS —, a burguesia local também buscou institucionalizar a comunhão de seus interesses". ${ }^{115}$

Em uma reunião dos proprietários de diversas fábricas de Porto Alegre ocorrida no Clube Caxeiral, eles concordaram com a iniciativa e acordaram em propor aos operários o estabelecimento da média de nove horas de trabalho, entre outras deliberações, como a de solicitar que as autoridades policiais garantissem a liberdade daqueles que desejassem trabalhar. ${ }^{116}$ A nova entidade se denominaria União Industrial e a comissão destinada a elaborar seus estatutos compôs-se de modo a contemplar os diferentes ramos da indústria: Alberto Bins (ferros), Victor Barreto (calçados), Francisco Herzog (madeiras), Otto Fenselau (tecidos) e Neugebauer (doces). Participariam da associação grandes e pequenos industriais, contribuindo cada um de acordo com o tamanho do seu estabelecimento. Poderiam participar, inclusive, as oficinas menores, que, na opinião dos industriais, só teriam a lucrar com seu ingresso na entidade. ${ }^{17}$

Em outra reunião do patronato, ainda durante a greve de 1906, desta vez no salão da Usina Elétrica, Alberto Bins apresentou a proposta de um representante dos operários, que havia lhe sugerido que, se os proprietários reduzissem a jornada de trabalho para $81 / 2$ horas, os grevistas voltariam ao trabalho, advogando logo a seguir que a jornada fosse modificada para $83 / 4$ horas. ${ }^{118}$ Tal proposta, aparentemente pouco atrativa para o operariado, pode ser compreendida se observarmos que a greve significa muito mais do que uma disputa meramente econômica, por salários, pois representa a possibilidade de resgate da honra e da dignidade dos trabalhadores, fazendo com que eles se sintam importantes. Um exemplo, embora bastante posterior, parece corroborar essa interpretação: em depoimento colhido no decorrer de uma greve dos operários metalúrgicos em São Paulo, Frederico, um operário, afirmou que a greve é "[...] mais pela honra do cara do que pelo aumento". ${ }^{119}$ Voltando ao contexto aqui em estudo, essa diferença de quinze minutos sugerida pelo líder operário pode ser encarada, então, muito mais como uma tentativa de resguardar o orgulho dos trabalhadores, para que eles não tivessem que acatar a proposta dos patrões, ferindo a dignidade do grupo. A greve havia se tornado uma questão de princípios, colocando em xeque a posição de liderança, tanto de Francisco Xavier da Costa quanto de Alberto Bins. ${ }^{120}$

Bins informou-lhe, então, que teria de apresentar a proposta a seus colegas, porém votaria contra. Encaminhada a reivindicação aos proprietários, esta foi rechaçada por ser vista como um aviltamento. ${ }^{121}$ Os empresários acabaram acatando a sugestão de Bins e rejeitando "por unanimidade, a proposta, alegando que essa

115 SCHMIDT, Op. cit., 2005, p. 53.

116 Esta exposição está baseada, principalmente, nos números do periódico O Independente publicados entre os dias 4 e 21 de outubro de 1906.

117 PESAVENTO, Op. cit., 1988, p. 245.

118 O representante operário que trouxe esta proposta aos industrialistas foi, segundo Schmidt, Francisco Xavier da Costa, que "tentando garantir a sua posição de efetivo negociador — ainda apresentou a contraproposta de uma jornada de 8 horas e três quartos, a qual, segundo ele, caso fosse aprovada, seria aceita por todos os trabalhadores, que imediatamente voltariam às fábricas e oficinas". SCHMIDT, Op. cit., 2005, p. 67.

119 Trecho de depoimento colhido em uma das greves dos anos 1978-1980. ABRAMO, L. W. Greve metalúrgica em S. Bernardo: sobre a dignidade do trabalho. In: CARDOSO, Ruth Correa et al. As lutas sociais e a cidade. São Paulo: Paz e Terra, 1991, p. 214.

120 SCHMIDT, Op. cit., 2005, p. 67.

121 Esta exposição está baseada, principalmente, nos números do periódico O Independente publicados entre os dias 4 e 21 de outubro de 1906. 
concessão seria humilhante aos industrialistas que argumentavam já terem sofrido inúmeras ofensas por grosserias ditas pelos grevistas em comícios e panfletos". ${ }^{122}$ Nessa reunião, ficou combinado, também, que a discussão acerca da criação da União Industrial só seria retomada após o término da greve, quando chegasse do Rio de Janeiro o modelo de um estatuto de uma associação similar.

A respeito da atitude dos patrões nesta "parede", Bilhão ressalta que, apesar das evidências estampadas nos jornais, "o grupo dos industrialistas e construtores já não se encontra[va] tão coeso", pois, contrariando o convênio firmado em reuniões anteriores, alguns construtores acataram a reivindicação de oito horas diárias de trabalho. ${ }^{123}$ Da mesma forma, outros industrialistas também estabeleceram acordos em separado com seus funcionários, o que evidencia tensões e divergências nas estratégias dos patrões. Nicolau Rocco, da Confeitaria Rocco, foi mais longe: além de conceder as oito horas a seus funcionários, abriu uma subscrição para auxiliar os grevistas, tendo doado 100 mil réis!'124 Em 1906, a possibilidade de se fundar uma agremiação capaz de congregar os interesses do patronato porto-alegrense foi aventada como uma resposta à crescente organização dos operários. Em 1919, tornou-se necessário, novamente, apelar para a união da classe patronal com a finalidade precípua de enfrentar o ascenso mobilizatório dos trabalhadores da capital que, como percebi, vinham deflagrando ininterruptas greves, as quais proporcionavam ganhos aos operários.

No mês de julho, o Sindicato dos Metalúrgicos declarou-se em greve, exigindo oito horas de trabalho e aumento de salário. As comissões de operários encarregadas de negociar com os patrões informaram que os srs. Mabilde \& Cia., Edgar Booth $^{125}$ e Francisco Clausen haviam acedido em adotar o horário proposto. Quanto às demais oficinas, embora tivessem sido entregues ofícios aos seus proprietários, as respostas ainda estavam sendo aguardadas. ${ }^{126}$ Ou seja, os patrões estavam sendo pressionados e muitos acabavam por ceder às exigências do operariado. Nessa direção, o jornal Correio do Povo noticiou que os estabelecimentos dos "srs. Alcaraz \& Cia., Só Filhos, José Becker \& Irmão, Jacques Maas, Cypriano Micheletto \& Irmão, Otto Outeiral, Bromber \& Cia, Guilherme Knack e João R. Alves resolveram adotar [...] a jornada de 8 horas, conforme solicitavam os operários". ${ }^{127}$

Apesar de alguns empregadores terem atendido ao que fora pleiteado pelos metalúrgicos, em reunião dos proprietários de estabelecimentos dessa natureza, ficou decidido, segundo proposição do major Alberto Bins (que parece ser, ao longo da Primeira República, o grande articulador da classe patronal porto-alegrense), que eles não iriam ceder às reivindicações, argumentando que tramitava no Congresso Nacional uma lei que regulamentava a jornada de trabalho em oito horas e, se eles adotassem a redução de jornada, ficariam prejudicados pela concorrência, o que também prejudicaria os próprios operários em função da diminuição do movimento naqueles estabelecimentos. ${ }^{128}$

Durante essa reunião, os proprietários das metalúrgicas encontravam-se divididos e defendiam propostas opostas. Enquanto Joaquim Alcaraz sugeria que os patrões "acedessem ao pedido dos operários, concedendo-lhes a jornada de

\footnotetext{
122 BILHÃO, Isabel, Op. cit., p. 53.

123 Idem, p. 54.

124 SCHMIDT, Op. cit., 2005, p. 62.

125 Uma curiosidade: Edgar Booth foi o autor do primeiro gol em Grenais. Além disso, foi "o pivô da primeira briga em gre-nais". BUENO, Eduardo. Grêmio: nada pode ser maior. Rio de Janeiro: Ediouro, 2005, p. 86. 126 Correio do Povo, Porto Alegre, 18 jul. 1919, p. 4.

127 Correio do Povo, Porto Alegre, 17 ago. 1919, p. 3.

128 Correio do Povo, Porto Alegre, 18 jul. 1919, p. 4 e 23 jul. 1919, p. 4.
} 
trabalho de 8 horas", Alberto Bins sustentava que se deveria aguardar a aprovação da referida lei que tramitava no Congresso. $O$ último alegava que, caso se adotasse a redução da jornada de trabalho nas indústrias da cidade, tal medida "colocaria os estabelecimentos metalúrgicos desta capital em condição de inferioridade em relação a estabelecimentos de localidades próximas onde vigoram horários de 9 , 10 e até mais horas de trabalho". ${ }^{29}$ O Syndicalista, ao comentar tal encontro, ironizou Alberto Bins, por ele ter reunido a "congregação abissínica" e falado "pesadamente, prussianamente", contra os "malandros que fizeram o desaforo de se declarar em greve". ${ }^{130}$ Mesmo os patrões que concordaram em atender a reivindicação do sindicato foram criticados pelo jornal, uma vez que esses - chamados de "cérebros de lama" - "resolveram estabelecer as 8 horas mas não assinam nem reconhecem o Comitê nem a greve, como se fossem deuses ou homens de palavra". ${ }^{131}$ Provavelmente, essa crítica dos operários se devia ao fato de que, em anos anteriores, alguns proprietários também concordaram com a jornada de oito horas e, logo depois, retomaram as jornadas mais longas. ${ }^{132}$

Quando a greve se generalizou, no final de agosto, os patrões vinham atuando de modo atomizado, o que lhes colocava em uma situação de vulnerabilidade diante de seus funcionários, tornando-os "reféns" de suas exigências. Segundo Mertz, "o fato de os industriais não se encontrarem arregimentados em um órgão de classe [...] contribuiu para que optassem por uma atuação individual, ou seja, a [sic] nível de empresa". ${ }^{133}$ Como reportado, durante a greve dos metalúrgicos, Alberto Bins tentou sem sucesso unificar a posição dos proprietários a fim de que ninguém atendesse às demandas dos operários. Porém, no início de setembro, quando as greves estouravam de maneira bastante rápida, os patrões realizaram uma reunião no Clube do Comércio. A ela compareceram os proprietários e diretores dos seguintes estabelecimentos: “Força e Luz Porto-Alegrense, Fiação e Tecidos Porto-Alegrense, Têxteis Sul-Brasileira, Fabril Porto-Alegrense, Moinho Rio-Grandense, Eduardo Sommer, Oscar Teichmann, Moinho Rio-Grandense, Rodolpho Traptow, Serraria Garibaldi, Becker \& Cia., Bopp \& Irmãos, B. Sassen, Ritter \& Cia., Tertuliano G. Borges e outros representantes". ${ }^{134}$

Nesse encontro, estabeleceu-se a resolução de que os empresários não fariam nenhuma concessão aos grevistas e foi deliberada, por unanimidade de votos, a atuação em comum acordo. Decidiu-se, ainda, realizar uma grande reunião da classe, "a fim de serem tomadas as deliberações definitivas". ${ }^{35}$ Alguns dias depois, o jornal A Federação noticiou que "os industriais e comerciantes desta praça, proprietários de estabelecimentos cujo pessoal se acha em greve, resolveram não realizar nova reunião conforme tinham combinado, visto se acharem todos dispostos a não aceder às pretensões dos operários em greve". ${ }^{136}$ Tal postura dos patrões porto-alegrenses divergiu da adotada no mesmo ano por seus congêneres

129 Correio do Povo, Porto Alegre, 23 set. 1919, p. 3.

130 O Syndicalista, Porto Alegre, 02 ago. 1919, p. 3.

131 Grevistas invencíveis cada vez mais conscientes. Aos metalúrgicos e aos operários em geral, Porto Alegre, 16 ago. 1919. Anexo 17. In: ESTADO DO RIO GRANDE DO SUL. Processo-Crime n. ${ }^{\circ} 1.016$, Porto Alegre: 1919.

132 Bilhão, por exemplo, enfatiza que, durante a greve geral de 1906, alguns comerciantes que chegaram a "efetuar um acordo com os funcionários pelo qual as portas deveriam ser fechadas às 20 horas" romperam com seu compromisso e continuaram a fechar seus estabelecimentos no horário habitual, 21 horas. Em virtude disso, teriam recebido estrondosas vaias de trabalhadores. BILHÃO, Isabel. Rivalidades e solidariedades no movimento operário: Porto Alegre, 1906-1911. Porto Alegre: EdiPUCRS, 1999, p. 54.

133 MERTZ, Marli. A burguesia industrial gaúcha e suas tentativas de organização: de sua origem a 1930. Ensaios FEE, Porto Alegre, v.12, n.2, 1991, p. 424.

134 Correio do Povo, Porto Alegre, 03 set. 1919, p. 6.

135 Idem.

136 A Federação, Porto Alegre, 05 set. 1919, p. 5. 
paulistanos durante a greve geral ocorrida no mês de maio naquela cidade, quando os proprietários negociaram diretamente com seus operários, não adotando uma posição conjunta como na capital gaúcha. Lá, alguns operários "saíram vencidos totalmente, outros parcialmente e alguns vencedores". ${ }^{137}$ Isso porque a simples posição de classe - propriedade dos meios de produção - não implica necessariamente determinada ação política classista. Como evidenciei, no caso de Porto Alegre, ao contrário da capital paulista, a ideia de se organizar a classe patronal já vinha de, pelo menos, 1906.

Percebo, também, no processo analisado, uma nítida influência da questão étnica na organização da classe patronal porto-alegrense. Como observei na primeira parte deste artigo, o patronato da capital era composto por significativo número de teutodescendentes ou mesmo de imigrantes alemães, fazendo com que as identidades étnicas e de classe se mesclassem entre o empresariado porto-alegrense. Anteriormente, durante a greve de 1906, a conformação étnica desse patronato já havia sido determinante para os rumos do movimento. Bak, ao tratar de tal aspecto, destaca que, em 1906, "a etnicidade compartilhada [dos proprietários] era algo em comum que inicialmente permitiu que os empresários de origem alemã se movimentassem com respostas individuais, dadas aos trabalhadores em um estabelecimento, para respostas coletivas de um empresariado unido, direcionadas a todo o movimento grevista". ${ }^{138}$ Conforme demonstrei antes, o mesmo ocorreu em 1919, quando o componente étnico reforçou a identidade de classe. A composição étnica do patronato local - com muitos teutodescendentes - e os laços econômicos e pessoais estabelecidos entre eles reforçaram um sentimento de unidade, de coesão.

Ao longo deste período, observei o que poderia chamar de "fazer-se" da classe patronal, que acabou por sair de uma situação de atomização, vulnerabilidade e fragilidade diante das agitações operárias para perfilhar uma postura coletiva e organizada, o que acarretava no seu fortalecimento nesse enfrentamento, resultando, muitas vezes, em um esvaziamento das greves. Segundo Pesavento, uma "ação coletiva implica um processo de maior amadurecimento da classe". 139 Para a autora, "o processo de amadurecimento e de autoidentificação de uma classe é lento e complexo. No caso do empresariado industrial gaúcho, ele dependeu tanto da consolidação de condições objetivas que lhe deram nascimento - a emergência da fábrica no seio de uma sociedade agrária — quanto da conjuntura política que assistiu à sua estruturação enquanto fração de classe". ${ }^{140}$

Para Thompson, é equivocado supor que a classe seja uma coisa, "tomada como tendo uma existência real, capaz de ser definida quase matematicamente". ${ }^{141}$ Ela se constitui, se forma por meio da experiência. As classes

não existem como entidades separadas que olham ao redor, acham um inimigo de classe e partem para a batalha. Ao contrário, para mim, as pessoas se veem numa sociedade estruturada de certo modo (por meio de relações de produção fundamentalmente), suportam a exploração (ou buscam manter poder sobre os explorados), identificam os nós dos interesses antagônicos, debatem-se em torno desses mesmos nós e, no curso de tal processo de luta, descobrem a si mesmas como uma classe. ${ }^{142}$

137 RODRIGUES, Edgar. Trabalho e Conflito: pesquisa histórica (1906/1937). Rio de Janeiro: Ed. Arte Moderna, 1975, p. 213.

138 BAK, Joan. Classe, etnicidade e gênero no Brasil: a negociação de identidade dos trabalhadores na Greve de 1906, em Porto Alegre. MÉTIS: história \& cultura, v.2, n.4, p. 181-224, 2003 , p. 36.

139 PESAVENTO, Op. cit., 1988, p. 15.

140 Idem, p. 238.

141 THOMPSON, E. P. A formação da classe operária inglesa. 1.ed. Rio de Janeiro: Paz e Terra, 1987, p. 10.

142 THOMPSON, E. P. Algumas observações sobre classe e 'falsa consciência'. In: NEGRO, A. L.; SILVA, Sergio. (org.). As peculiaridades dos ingleses e outros artigos. Campinas: Edunicamp, 2001, p. 274. 
Desse modo, é crível supor que o patronato porto-alegrense, no processo de defesa de seus interesses e buscando manter sua dominação, passasse a se descobrir como classe, optando pela adoção de estratégias coletivas de enfrentamento. Para o autor, classe

\begin{abstract}
é uma formação social e cultural (frequentemente adquirindo expressão institucional) que não pode ser definida abstrata ou isoladamente, mas apenas em termos de relação com outras classes; e, em última análise, a definição só pode ser feita através do tempo, isto é, ação e reação, mudança e conflito. Quando falamos de uma classe, estamos pensando em um corpo de pessoas, definido sem grande precisão, compartilhando as mesmas categorias de interesses, experiências sociais, tradição e sistema de valores, que tem disposição para se comportar como classe, para definir, a si próprio em suas ações e em sua consciência em relação a outros grupos de pessoas, em termos classistas. Mas classe, mesmo, não é coisa, é um acontecimento. ${ }^{143}$
\end{abstract}

A experiência social compartilhada durante a onda de reivindicações operárias ocorrida, especialmente entre 1917 e 1919, pelo patronato porto-alegrense levou a uma tomada de consciência de que, para a conservação de seu status quo, seria necessária a adoção de medidas coletivistas. Assim, a despeito de Bourdieu afirmar que as estratégias de conservação/sucessão dos grupos dominantes partem do princípio de que não há a formação de um grupo constituído coletivamente, mas sim, práticas concorrenciais ${ }^{144}$, nesse momento, a burguesia da capital quebrou seu isolamento e buscou um enfrentamento coletivo, com tomadas de posições classistas (a despeito de alguns empregadores haverem descumprido as combinações).

No caso aqui analisado, a ação intransigente adotada de modo coletivo pelo patronato a fim de enfrentar os grevistas surtiu efeito, visto que, em 1919, a paralisação terminou sem que a maioria das categorias envolvidas no movimento tivesse sido bem-sucedida em suas reivindicações. A posição dos patrões, enrobustecida pela ação do governo do estado - que repreendeu severamente o movimento —, foi vitoriosa e conseguiu debilitar a organização operária. O ano de 1919 foi, enfim, o crepúsculo das grandes greves da Primeira República.

No dia 15 de setembro, a Gazeta do Povo dava como "conjurada" a greve e questionava: "qual foi o proveito advindo para as classes trabalhadoras resultante desse movimento?". ${ }^{145}$ Como vimos, o periódico atribuía a culpa pela greve aos conselhos dos "espíritos obcecados com a leitura de panfletos rubros". ${ }^{146}$ Ainda houve uma tentativa de realizar um novo meeting na praça Conde de Porto Alegre que, contudo, acabou sendo proibido pela polícia. ${ }^{147}$ Era o final melancólico de um movimento que se iniciara vigoroso.

Apenas a partir da segunda metade da década de 1920, novamente com a liderança de Alberto Bins, os industriais, reunidos na Associação Comercial de Porto Alegre, passaram a (re)discutir a formação de uma entidade própria. A fundação de uma associação representativa dos industriais gaúchos efetivou-se somente em novembro de 1930, com a criação do Centro de Indústrias Fabris do Rio Grande

143 THOMPSON, E. P. Folclore, antropologia e história social. In: NEGRO, Antonio Luigi; SILVA, Sergio (orgs.). Idem, p. 169.

144 BOURDIEU, Op. cit., 1983, p. 201.

145 Gazeta do Povo, Porto Alegre, 15 set; 1919, p. 1.

146 Gazeta do Povo, Porto Alegre, 15 set. 1919, p. 1.

147 Correio do Povo, Porto Alegre, 16 set. 1919, p. 5. 
do Sul (Cinfa), uma consequência direta dos eventos relacionados à chamada Revolução de 30 e ao isolamento ao qual o estado foi submetido naquele contexto, e da necessidade da classe de organizar-se, mais uma vez, para enfrentar e controlar a chamada "questão social". ${ }^{148}$

A greve aqui examinada acabara. A união dos patrões, apoiados pelo governo, dobrou a resistência dos sindicatos operários, e suas lideranças - denominadas pela grande imprensa como "aves de arribação" — sofreram um abalo em sua credibilidade. Os "traços infernais", bem como seus "ideais macabros", haviam sido derrotados — ao menos naquele momento...

Concluo, portanto, que, no repertório de estratégias do patronato porto-alegrense acionado ao longo desses movimentos paredistas, a insistência na demissão de operários grevistas e o apelo ao estado para proteger seus interesses contra a ação organizada dos trabalhadores eram práticas corriqueiras dos patrões durante as greves. A postura do patronato foi marcada pela tentativa de responder às ações dos operários, que protagonizavam, de forma coletiva e associativa, protestos e reivindicações, os quais ameaçavam a tranquilidade da ordem burguesa. Assim, a reação patronal era marcada pela repressão, pela coerção e pela "sedução" para que os grevistas retomassem o trabalho (e para que outros empregados não aderissem a tais mobilizações). Demissões e lockouts eram comuns no sentido de procurar fazer as greves fracassarem. Todavia, apesar disso, a ação coletiva dos trabalhadores obteve êxito em certas ocasiões, levando os patrões a buscar uma postura associativa, coletiva. Ou seja, a mobilização dos trabalhadores da capital engendrou um "fazer-se" da classe patronal, uma tentativa de organização dessa classe para defender seus interesses perante as organizações operárias. Nesse processo, ao adotarem ações coletivas e unificadas contra as paredes, os patrões, embora não tenham criado uma associação formal, constituíram-se e se fortaleceram enquanto classe. Tal união, por mais que só tenha se efetivado de forma mais acabada em termos institucionais na década seguinte, foi decisiva para que as greves generalizadas de 1919 acabassem em fracasso para o operariado.

Recebido em 28/10/2012

Aprovado em 26/01/2013

148 PESAVENTO, Op. cit., 1988, p. 252. 
